\title{
PERANCANGAN ALGORITMA PADA PENGEMBANGAN OTOMATISASI SISTEM RABBIT PNEUMATIK DI REAKTOR RSG-GAS
}

\section{ALGORITHM DESIGN IN AUTOMATIZATION OF PNEUMATIC RABBIT SYSTEM IN RSG-GAS REACTOR}

\author{
Sunarko ${ }^{1}$, Hanapi $\mathrm{Ali}^{2}$ \\ ${ }^{1}$ Pusat Reaktor Serba Guna-BATAN, Kawasan Puspiptek Serpong \\ Email : narko@batan.go.id \\ 2 Pusat Reaktor Serba Guna-BATAN, Kawasan Puspiptek Serpong \\ Email : hanapiali@batan.go.id
}

Diterima : 2 Oktober 2020, diperbaiki : 18 Oktober 2020, disetujui : 22 Oktober 2020

\begin{abstract}
ABSTRAK
PERANCANGAN ALGORITMA PADA PENGEMBANGAN OTOMATISASI SISTEM RABBIT PNEUMATIK DI REAKTOR RSG-GAS. Algoritma merupakan urutan langkah-langkah kegiatan atau proses dalam suatu sistem. Perancangan Algoritma ini akan dipergunakan untuk menentukan langkah pada sistem otomatisasi rabbit pneumatik. Algoritma ini merupakan alur pemikiran dalam merancang perangkat lunak pada sistem otomatisasi pengirim kapsul penumatic rabbit yang sedang dikembangkan oleh PRSG. Tujuan dari tulisan ini adalah merancang Algoritma untuk menentukan pembuatan perangkat lunak sehingga sistem dapat beroperasi secara otomatis. Langkah awal otomatisasi dimulai dengan pengaturan waktu iradiasi, kemudian tekan tombol iradiasi. Ketika waktu iradiasi telah diisi dan tombol iradiasi ditekan maka solenoid valve terbuka dan suplai udara bertekanan akan medorong kapsul. Dalam perjalanannya kapsul setelah melewati sensor CG 002, maka media pendorong akan berganti ke gas Nitrogen yang akan bersirkulasi selama iradiasi berlangsung. Kapsul juga akan melewati sensor CG 001 untuk mengaktifkan waktu iradiasi setelah 1 detik. Proses iradiasi akan berlangsung sesuai dengan pengaturan waktu iradiasi, dan apabila waktu iradiasi selesai maka kapsul akan kembali secara otomatis menuju ke counter station di ruang Laboratorium AAN untuk dilakukan akusisi data. Dari counter station kapsul dapat dikirim kembali ke posisi iradiasi/re-iradiasi atau dikenal dengan sistem ping-pong. Jika re-iradiasi tidak diperlukan kapsul dapat dikirimkan menuju ke waste station untuk disimpan sebagai limbah. Perancangan algoritma akan digunakan sebagai dasar dalam pembuatan perangkat lunak.
\end{abstract}

Kata Kunci : Algoritma, otomatisasi, pneumatic, sistem rabbit

\begin{abstract}
ALGORITHM DESIGN IN AUTOMATIZATION OF PNEUMATIC RABBIT SYSTEM IN RSGGAS REACTOR. Algorithms are sequences steps of activity or process in a system. The design of this algorithm will be used to determine the steps in the automation pneumatic rabbit system. This algorithm is a plot of thought in designing software in the automation system sending of capsule rabbit penumatic that is being developed by PRSG. The purpose of this paper is to design an algorithm to determine the creation of software so that the system can be operated automatically. The initial step of automation start with setting the irradiation time, then press the irradiation button. When the irradiation time has been filled and the irradiation button is pressed the solenoid valve is opened and a pressurized air supply will push up the capsule. In the course of the capsule after passing the CG 002 sensor, the media will change to Nitrogen
\end{abstract}


gas which will circulate during irradiation. The capsule will also pass through the CG 001 sensor to activate the irradiation time after 1 second. The irradiation process will take place in accordance with the irradiation time setting, and when the irradiation time is complete the capsule will automatically return to the counter station in the AAN Laboratory room for data acquisition. From the counter station the capsule can be sent back to the irradiation position/ reirradiation or known as the ping-pong system. If re-irradiation is not needed capsule can be sent to the waste station to be stored as waste. The design of the algorithm will be used as a basis in making software.

Keywords: Algorithm, automation, pneumatic, rabbit system

\section{PENDAHULUAN}

\section{Salah satu fasilitas iradiasi di}

Reaktor Serba Guna G.A. Siwabessy (RSG-GAS) adalah fasilitas iradiasi Sistem Rabbit. Fasilitas ini dipergunakan untuk keperluan produksi radioisotop dan penelitian Analisis Aktivasi Neutron (AAN). Fasilitas Sistem Rabbit terdiri dari 2 jenis, yaitu Sistem Rabbit Hidrolik dan Sistem Rabbit Pneumatik. Sistem Rabbit Hidrolik menggunakan media pengangkut air, sedangkan Sistem Rabbit Pneumatik sebagai media pengangkutnya gas nitrogen. Media pengangkut juga berfungsi sebagai pendingin pada saat iradiasi berlangsung. Ditinjau dari sisi waktu pemakaian kedua jenis fasilitas tersebut mempunyai spesifikasi waktu iradiasi yang berbeda. Sistem Rabbit Hidrolik dapat digunakan untuk iradiasi dengan waktu antara 30 detik sampai 5 jam, dengan waktu tempuh pengiriman dan penerimaan kapsul target iradiasi masing-masing 45 detik ${ }^{[1,2,3]}$. Sistem Rabbit Pneumatik digunakan untuk iradiasi sampel yang mempunyai waktu paruh pendek dengan orde $<30$ detik, serta waktu tempuh bolak-balik kapsul target iradiasi hanya 8 detik $^{[2,3,4]}$.

Ketika iradiasi selesai diperlukan waktu penanganan dan pengukuran paparan radiasi terhadap kapsul teriradiasi. Waktu yang dibutuhkan lebih dari 30 detik, dengan demikian sampel dengan waktu paro pendek akan segera habis. Dan saat penanganan kapsul teriradiasi, operator fasilitas dan petugas proteksi radiasi akan terpapar radiasi karena berhadapan langsung dengan bahan aktif. Oleh karena itu diperlukan pemindahan penanganan kapsul, yang pada awalnya di dalam Hot Cell dipindahkan ke Ruang Cacah Laboratorium AAN (Lab. AAN). Sehingga kapsul yang akan diiradiasi dimasukan dari ruang Lab. AAN dan kembali lagi ke ruang yang sama dengan waktu tempuh balik kapsul hanya 4 detik ${ }^{[2,3,4]}$.

Sistem Rabbit Pneumatik sedang dikembangkan lebih lanjut oleh PRSG untuk mengurangi resiko paparan radiasi terhadap pekerja dan untuk koreksi waktu tunda pengiriman sampel dari $\mathrm{Hot}$ Cell ke ruang cacah Laboratorium AAN [2]. Dengan demikian diperlukan sistem otomatisasi pengiriman kapsul target iradiasi pada sistem Rabbit Pneumatik tersebut. Dalam rangka mendukung program otomatisasi sistem pengirim kapsul iradiasi Rabbit Pneumatik di RSGGAS maka diperlukan beberapa tahapan kegiatan, salah satunya adalah tahap perancangan algoritma.Perancangan Algoritma adalah rancangan urutan langkah-langkah logis untuk menyelesaikan suatu kasus/masalah yang disusun secara sistematis. Algoritma akan digunakan sebagai dasar untuk pembuatan perangkat lunak yang dapat menginstruksikan atau memerintah perangkat keras agar bekerja secara otomatis. Jadi perancangan algoritma ini 
sebagai salah satu langkah dalam proses perancangan sistem kendali pada sistem otomatisasi rabbit pneumatik.

\section{TEORI}

Kata "algoritma" diturunkan dari nama seorang ilmuwan Arab yang bernama Abu Jafar Muhammad Ibnu Musa Al Khuwarizmi penulis buku berjudul Al Jabar Wal Muqabala. Kata Al Khuwarizmi dibaca orang barat menjadi Algorism yang kemudian lambat laun menjadi Algorithm diserap dalam bahasa Indonesia menjadi Algoritma ${ }^{[5]}$. Algoritma merupakan metode umum yang digunakan untuk menyelesaikan kasuskasus tertentu [5,6,7]. Meski demikian terdapat beberapa definisi algoritma yang lain, diantaranya adalah :

> Rinaldi Munir, algoritma adalah urutan langkah-langkah logis penyelesaian masalah yang disusun secara sistematis.

> Kamus Besar Bahasa Indonesia, algoritma adalah urutan logis pengambilan keputusan untuk pemecahan masalah.

$>$ Tim Gunadarma:1988, algoritma adalah suatu himpunan berhingga dari instruksi-instruksi yang secara jelas memperinci langkah-langkah proses pelaksanaan, dalam pemecahan suatu masalah tertentu, atau suatu kelas masalah tertentu, dengan dituntut pula bahwa himpunan instruksi tersebut dapat dilaksanakan secara mekanik.

Dari pengertian di atas maka dapat disimpulkan bahwa Algoritma adalah ilmu yang mempelajari cara penyelesaian suatu masalah berdasarkan urutan langkah-langkah terbatas yang disusun secara sistematis dan menggunakan bahasa yang logis dengan tujuan tertentu ${ }^{[5]}$. Dalam penulisan algoritma terdapat 3 cara yang sering digunakan, yaitu : Kalimat deskriptif, Pseudocode dan Flowchart (diagram alir). Tabel 1. dibawah merupakan simbol-simbol yang digunakan untuk membuat flowchart.

Tabel 1. Fungsi simbol pada Flowchart

KETERANGAN
$\begin{aligned} & \text { Terminator : sebagai simbol START/END, untuk } \\ & \text { memulai atau mengakhiri flowchart. }\end{aligned}$
$\begin{aligned} & \text { Conditional / Decision : digunakan untuk pernyataan } \\ & \text { kondisi atau pengambilan keputusan. }\end{aligned}$
$\begin{aligned} & \text { Input/Output : digunakan untuk mnerima data atau } \\ & \text { mengeluarkan data. }\end{aligned}$
$\begin{aligned} & \text { Predefined Process : digunakan untuk menjalankan } \\ & \text { fungsi/prosedur/sub-program. }\end{aligned}$
$\begin{aligned} & \text { Manual operation : berfungsi untuk menunjukkan } \\ & \text { pengolahan yang tidak dilakukan oleh komputer/pc } \\ & \text { (misalnya tombol). }\end{aligned}$
$\begin{aligned} & \text { Preparation : digunakan untuk memberikan nilai awal. } \\ & \text { Connector (on-page) : penyambung flowchart pada } \\ & \text { satu halaman. }\end{aligned}$




\begin{tabular}{l}
$\square$ \\
$\longrightarrow \quad \begin{array}{l}\text { Connector (off-page) : penyambung flowchart pada } \\
\text { halaman yang berbeda. }\end{array}$ \\
$\begin{array}{l}\text { Arrow : digunakan sebagai penunjuk arah alur proses } \\
\text { algoritma. }\end{array}$ \\
\hline
\end{tabular}

Flowchart merupakan bagan atau gambaran yang memperlihatkan urutan dan hubungan antar proses, dan dinyatakan dengan simbol. Sebuah flowchart selalu dimulai dengan "start" dan boleh diakhiri dengan "finish" atau tidak diakhiri, hal ini menunjukan bahwa satu sistem perangkat memiliki proses operasi dari permulaan sampai akhiran. Dengan menggunakan flowchart akan memudahkan kita untuk melakukan pengecekan bagian-bagian yang terlupakan dalam analisis masalah.

Perancangan algoritma pada pengembangan otomatisasi sistem rabbit pneumatik di Reaktor RSG-GAS merupakan salah satu bagian dalam perancangan sistem kendali dan akan digunakan sebagai dasar dalam pembuatan perangkat lunak. Perangkat lunak merupakan otak dari sistem kendali, sehingga perangkat keras dapat beroperasi secara otomatis saat menerima masukan dari operator. Perancangan algoritma pada sistem otomatisasi rabbit pneumatik terdiri dari :

Algoritma sub program iradiasi adalah proses pengiriman kapsul yang akan diiradiasi menuju posisi iradiasi dan kembalinya kapsul teriradasi ke counter station.

Algoritma sub program re-iradiasi adalah proses pengiriman kapsul teriradiasi dari counter station menuju posisi iradiasi dan kembali lagi ke counter station (iradiasi ulang).

Algoritma sub program waste adalah alur perjalanan kapsul dari counter station setelah dilakukan pengukuran menuju ke tempat penyimpanan limbah kapsul
Algoritma sub program timer adalah alur penundaan waktu dari awal proses suatu sistem sampai dengan selesai

\section{Analisis $^{[9]}$}

Algoritma yang baik adalah alur proses yang dapat menyelesaikan masalah dengan optimal dan tidak menimbulkan masalah yang baru. Sebuah algoritma yang baik memiliki sifat-sifat berikut:

1. Benar, di mana algoritma menyelesaikan masalah dengan tepat, sesuai dengan definisi masukan / keluaran algoritma yang diberikan.

2. Efisien, berarti algoritma menyelesaikan masalah tanpa memberatkan bagian lain dari aplikasi.

3. Mudah diimplementasikan, artinya sebuah algoritma yang baik harus dapat dimengerti dengan mudah sehingga implementatif.

Pada kenyataan prakteknya, belum tentu ketiga hal tersebut dapat selalu tercapai. Kebenaran dari sebuah algoritma umumnya dapat dicapai, setidaknya untuk nilai-nilai masukan umum, tetapi efisiensi dan kemudahan implementasi tidak selalu didapatkan dengan tepat. Walau begitu, tentunya kita harus tetap berusaha mencapai ketiga hal tersebut dalam merancang sebuah algoritma. Definisi dari kebenaran algoritma yang digunakan adalah sebagai berikut:

"Sebuah algoritma dikatakan telah benar jika algoritma tersebut dapat memberikan keluaran yang benar jika menerima masukan sesuai dengan definisi algoritma tersebut, dan algoritma 
tersebut terbukti akan selalu diterminasi (berakhir)".

\section{METODOLOGI}

\section{Identifikasi}

Identifikasi kebutuhan dalam perancangan algoritma berupa komputer, Diagram Perpipaan Sistem Otomatisasi Rabbit Pneumatik dan deskripsi sistem instrumentasi kendali. Diagram Perpipaan Sistem Otomatisasi Rabbit Pneumatik ditunjukan seperti pada gambar 1. Pengertian dari piping and instrumen drawing adalah sebuah alat bantu diagram/gambar skema untuk menerangkan konsep desain dari sebuah proses yang dibangun. Bisa disebut juga sebagai illustrasi skematik dari hubungan fungsional perpipaan, instrumentasi dan peralatan/komponen pendukung sistem lainnya. Perbedaan mendasar dari gambar skema ruang pada gambar pipa, terletak pada gambar pipa dan instrumen lebih lengkap menggambarkan bekerjanya sistem. Berikut adalah gambar perpipaan pengembangan sistem otomatisasi rabbit pneumatik.

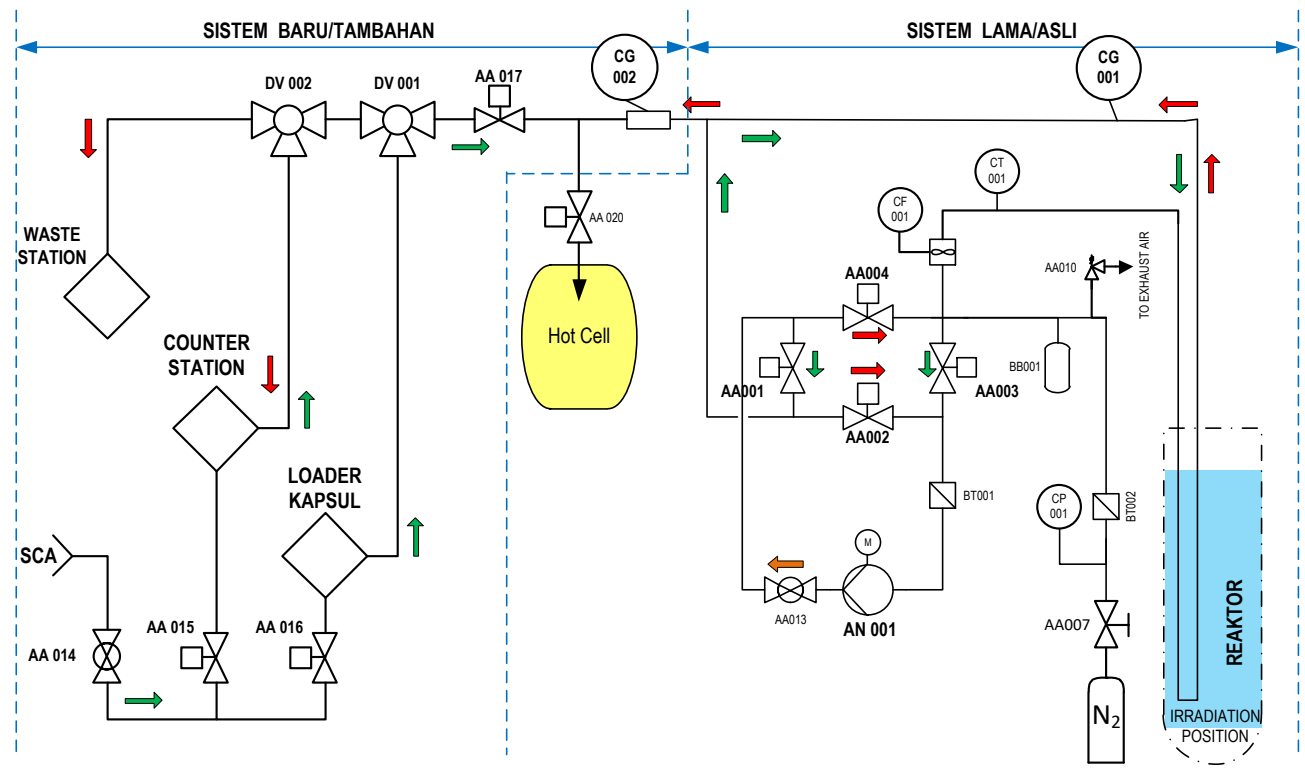

Gambar 1. Diagram Perpipaan Sistem Otomatisasi Rabbit Pneumatik ${ }^{[8]}$.

Tabel 2. Daftar Komponen Utama pada Sistem Otomatisasi Rabbit Pneumatik

\begin{tabular}{rll}
\hline NO & \multicolumn{1}{c}{ KOMPONEN } & \multicolumn{1}{c}{ KETERANGAN } \\
\hline 1. & SCA & Supply Compresed Air (suplai udara bertekanan) \\
\hline 2. & AA014 & Ball Valve \\
\hline 3. & AA015 & Solenoid Valve 220 VAC \\
\hline 4. & AA016 & Solenoid Valve 220 VAC \\
\hline 5. & WASTE STATION & Tempat limbah kapsul \\
\hline
\end{tabular}




\begin{tabular}{|c|c|c|}
\hline 6. & COUNTER STATION & Tempat pencacahan kapsul \\
\hline 7. & LOADER KAPSUL & Tempat pemasukan kapsul yang baru \\
\hline 8. & DV001 & Diverter Valve (Valve 1 input 2 output) \\
\hline 9. & DV002 & Diverter Valve (Valve 1 input 2 output) \\
\hline 10. & AA017 & Solenoid Valve 220 VAC \\
\hline 11. & CG002 & Sensor Laser \\
\hline 12. & AA001 & Solenoid Valve 24 VDC \\
\hline 13. & AA002 & Solenoid Valve 24 VDC \\
\hline 14. & AA003 & Solenoid Valve 24 VDC \\
\hline 15. & AA004 & Solenoid Valve 24 VDC \\
\hline 16. & AA013 & Ball Valve \\
\hline & AN001 & Motor Ventilator \\
\hline & BT001 & Filter Udara \\
\hline 19. & BT002 & Filter Udara \\
\hline 20. & CP001 & Alat Ukur Tekanan \\
\hline 21. & AA007 & Valve pada tabung Gas Nitrogen \\
\hline 22. & N2 & Tabung Gas Nitrogen \\
\hline 23. & BB001 & Reservoir \\
\hline 24. & AA010 & Safety Valve \\
\hline 25. & CF001 & Alat Ukur Aliran \\
\hline 26. & СТ001 & Alat Ukur Temperatur/Suhu \\
\hline 27. & CG001 & Sensor Infra Merah \\
\hline 28. & AA020 & Solenoid Valve 24 VDC \\
\hline
\end{tabular}

Sesuai dengan Gambar 1 di atas bahwa kondisi instalasi yang lama pengiriman dan penerimaan kapsul iradiasi melalui isotope cell. Selanjutnya kapsul iradiasi dibawa secara manual ke ruang cacah Laboratorium AAN. Kemudian dikembangkan dengan ditambahkan instalasi baru, sehingga pengiriman dan penerimaan kapsul iradiasi dapat dilakukan langsung dari ruang cacah Laboratorium AAN. Dalam hal pengiriman dan penerimaan kapsul iradiasi akan dilakukan secara otomatis. Suatu sistem otomatis dibutuhkan sistem instrumentasi dan kendali terdiri dari sensor, kontroler dan aktuator. Sensor berfungsi menentukan posisi dari aktuator dan nilai proses seperti flow air/gas yang mengalir, tekanan serta suhu. Aktuator dalam perancangan ini menggunakan diverter valve terdiri dari 2 jenis, yaitu jenis :

$>\quad$ diverter valve 1 input 2 output. $>\quad$ diverter valve 2 input 1 output.

Kedua diverter valve tersebut digerakkan oleh motor stepper. Untuk menentukan kondisi dari kedua keadaan output/input tersebut digunakan limit switch. Proses pengiriman dari kapsul pneumatik dimulai pada kapsul loader. Kapsul Loader adalah tempat kapsul yang siap dikirim ke posisi iradiasi. Ketika kapsul berada di loader, akan membangkitkan sinyal. Sinyal tersebut juga memerintahkan 
pada kontroler untuk menggerakan aktuator berada pada posisi menuju teras. Tombol iradiasi digunakan untuk mengirim sampel target menuju posisi iradiasi. Ketika tombol ditekan, sinyal akan diterima kontroler dan kontroler memerintahkan solenoid valve JBB05 AA013 membuka. Udara bertekanan akan mengirim kapsul menuju posisi iradiasi dalam hitungan detik. Sebelum target mencapai posisi iradiasi, kapsul target akan dideteksi oleh sensor JBB05 CG002. Sensor JBB05 CG002 berfungsi untuk menutup diverter valve JBB05 DV001, serta mengaktifkan sistem pendingin nitrogen untuk pendinginan kapsul target. Kerja sistem pendingin adalah membuat JBB05 AA01, dan JBB05 AA03 terbuka, serta blower JBB05 AN001 menyala. Sehingga sirkulasi nitrogen ke dalam posisi iradiasi dan kembali ke blower terjadi. Lama iradiasi target sampel tergantung dari permintaan pelanggan. Lama iradiasi terhitung ketika target sampel berada pada posisi iradiasi. Oleh karena itu diperlukan masukan berupa lama iradiasi pada sistem kendali dan instrumentasi. Masukan berupa bilangan bulat yang akan menghitung mundur waktu iradiasi. Tepat ketika pewaktu bernilai 0, maka JBB05 AA01, JBB05 AA03 tertutup, sedangkan JBB05 AA017, JBB05 AA02, dan JBB05 AA04 akan terbuka, sehingga meniupkan target sampel yang berada di posisi iradiasi keluar menuju ruang pencacah. Setelah sampel target dicacah maka target sampel akan menjadi limbah. Dengan menekan tombol waste, sampel target yang sudah diiradiasi akan dikirim ketempat penyimpanan sementara. Akan tetapi sampel target juga dapat diiradiasi ulang apabila diperlukan.

Instalasi perpipaan dan instrumentasi tidak akan dapat beroperasi tanpa dikendalikan oleh perangkat lunak, yang mana perangkat lunak adalah sebagai otak dalam mengolah masukan dan mengeluarkan perintah-perintah untuk menggerakkan perangkat keras. Perangkat lunak dibuat berdasarkan atas urutan langkah-langkah logis beroperasinya komponen yang telah dipasang. Langkah-langkah logis dalam penyelesaian masalah yang disusun secara sistematis inilah disebut algoritma. Pada perancangan algoritma kali ini akan digunakan flowchart. Flowchart merupakan alat bantu yang digunakan untuk menuangkan hasil pemikiran dalam menyelesaikan suatu kasus. Secara formal, flowchart didefinisikan sebagai skema penggambaran algoritma atau proses ${ }^{[7]}$

\section{Perancangan algoritma terdiri dari}

a) Perancangan Algoritma Utama

Perancangan algoritma utama pada pengembangan otomatisasi Sistem Rabbit Pneumatik digunakan untuk menentukan urutan langkah-langkah kerja pada setiap perangkat yang sudah diinstal pada sistem. Otomatisasi Sistem Rabbit Pneumatik dapat beroperasi apabila semua perangkat terinstal, bisa diinstruksikan nyala (ON) dan mati (OFF) sesuai dengan urutan perintah yang dikirimkan. Algoritma utama menggambarkan bahwa harus ada sinkronisasi antara sistem yang lama dengan sistem yang baru/tambahan.

\section{b) Perancangan Algoritma sub program iradiasi}

Sub program iradiasi adalah program yang akan mengerjakan urutan kerja dari mulai kapsul dimasukkan dalam kapsul loader sampai ke counter station. Sub program ini dapat diaktifkan dengan 3 syarat utama, yaitu waktu iradiasi sudah diatur, kapsul sudah 
terdeteksi dalam kapsul loader dan operator menekan tombol iradiasi.

c) Perancangan Algoritma sub program re-iradiasi

Sub program re-iradiasi dimaksudkan jika terjadi suatu kasus kapsul yang sudah diiradiasi tidak menunjukkan adanya keaktifan dari unsurnya, artinya proses iradiasi telah gagal, maka kapsul dapat dikirim menuju posisi iradiasi tanpa harus memindahkan kapsul kembali ke posisi loader. Pengaktifan sub program ini mengharuskan kapsul terdetek di dalam counter station dan operator menekan tombol reiradiasi setelah menentukan waktu iradiasi.

\section{d) Perancangan program waste}

Algoritma sub Sub program waste merupakan program yang akan mengeksekusi tindak lanjut target/kapsul yang sudah di cacah/diakusisi datanya. Untuk memudahkan sekaligus menghemat waktu maka, target tersebut dapat langsung dikirim menuju tempat penyimpanan limbah sementara.

\section{e) Perancangan Algoritma sub program timer}

Sub Program timer adalah program utama dari 2 sub program diatas, sub program iradiasi dan re-iradiasi. Karena kedua program ini memerlukan inputan berupa waktu lamanya iradiasi yang dibutuhkan dan juga penghitung mundur dari waktu yang telah ditentukan tersebut.

\section{HASIL DAN PEMBAHASAN}

\section{a) Hasil Perancangan Algoritma Utama}

Hasil perancangan algoritma utama ditunjukkan seperti diagram alir pada Gambar 2. Langkah awal dari algoritma utama setelah setting waktu dan tekan tombol iradiasi adalah inisialisasi sistem asli, yang mana sistem ini telah terinstal pada saat pembangunan reaktor oleh Interatom Gmbh German. Pada dasarnya sistem asli secara parsial sudah dilakukan pengecekan setiap perangkat yang terintegrasi. Namun langkah ini harus dilakukan kembali setelah diintegrasikan dengan sistem yang dikembangkan (sistem tambahan). Pengecekan pada sistem asli meliputi : sensor kapsul, solenoid valve, pompa, sensor tekanan dan tegangan supply. Pengecekan ini dilakukan karena sistem asli dibuat interlocking dengan sistem tambahan. Apabila sistem asli sudah siap maka tahapan selanjutnya adalah inisialisasi sistem tambahan. 


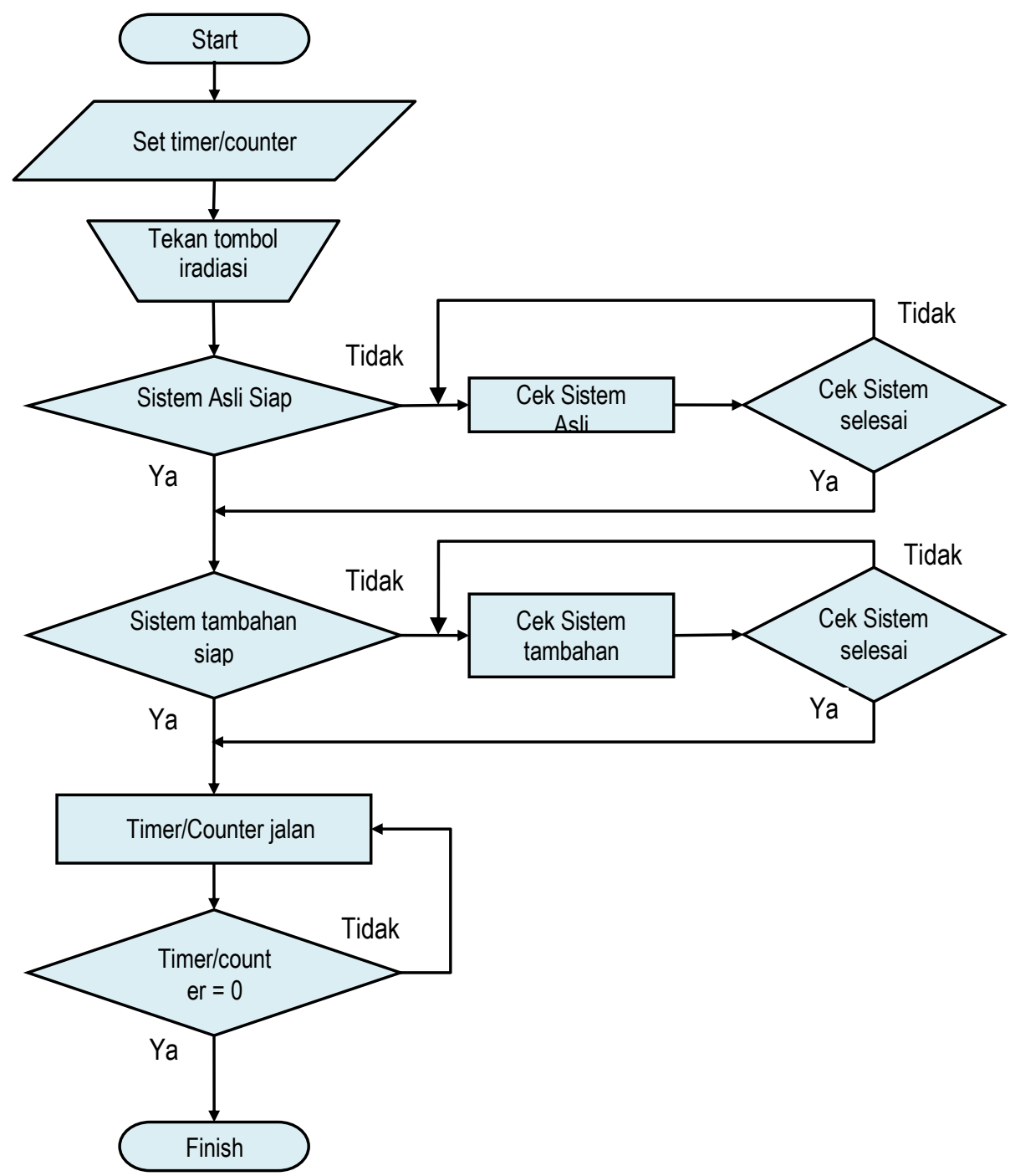

Gambar 2. Diagram alir proses iradiasi pada pengembangan otomatisasi Sistem Rabbit Pneumatik

Inisialisasi pada sistem tambahan dilakukan untuk mengetahui sejauh mana sistem siap menjalankan instruksi. Dalam inisialisasi sistem tambahan apabila sistem belum siap, maka akan dilakukan pengecekan perangkat yang sudah terinstal yang meliputi : solenoid valve, kapsul loader, diverter valve, knife gate valve, sensor kapsul dan power supply. Ketika semua perangkat sudah dinyatakan siap maka langkah selanjutnya adalah sistem timer/counter akan berjalan. Dalam hal ini Timer/counter adalah merupakan waktu iradiasi yang telah diseting pada awal proses. Jadi timer/counter akan berjalan menuju nilai "0" (nol), artinya ketika 
timer/counter sudah bernilai "0" proses iradiasi selesai. Begitu proses iradiasi selesai kapsul akan balik secara otomatis.

\section{b) Hasil Perancangan Algoritma sub program iradiasi}

Hasil perancangan Algoritma dari sub program iradiasi ini ditunjukan oleh Gambar 3. sebagai berikut :

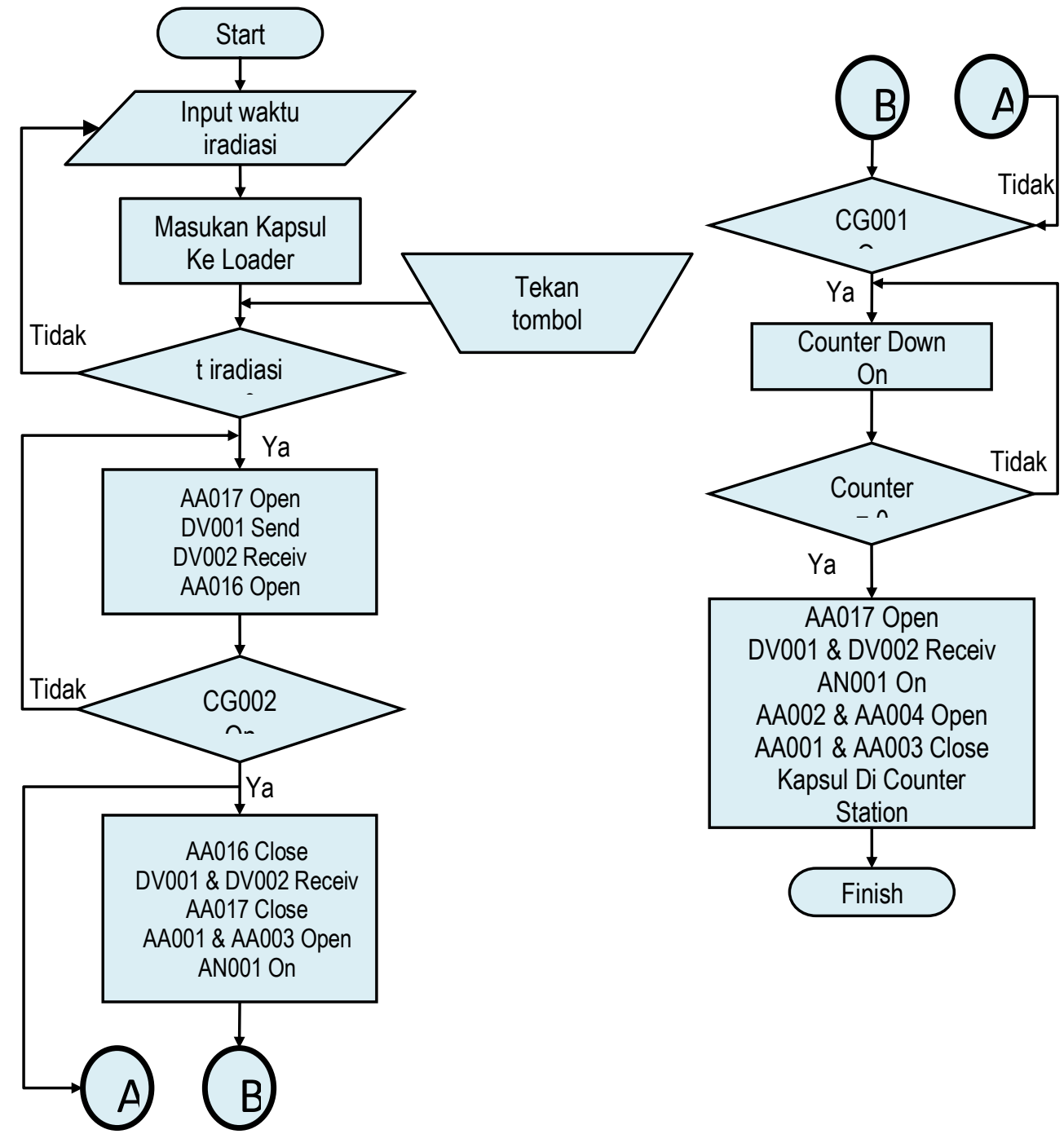

Gambar 3. Algoritma Sub Program Iradiasi

Algoritma sub program iradiasi adalah proses pengiriman kapsul yang akan diiradiasi menuju posisi iradiasi dan kembalinya kapsul teriradasi ke counter station. Pada perancangan algoritma sub program iradiasi seperti pada Gambar 3. diatas, dimulai dengan start, kemudian masukan waktu iradiasi sesuai permintaan pemohon. Selanjutnya kapsul dimasukan ke Loader Kapsul, dan dengan menekan tombol iradiasi maka 
proses pengiriman kapsul akan segera berjalan dengan syarat waktu iradiasi harus lebih besar dari nilai " 0 ". Namun apabila waktu iradiasi belum dimasukan $(\mathrm{t}=0)$, maka proses pengiriman kapsul tidak akan dilakukan. Dikarenakan solenoid valve AA 016 tidak terbuka, sehingga udara pendorong (SCA) juga tidak akan dapat mengalir. Sebagai catatan bahwa AA014 adalah stop valve manual, yang harus dibuka sebelum operasi sistem secara otomatis. Jika waktu iradiasi sudah dimasukan ( $\mathrm{t}>0$ ), maka AA017 terbuka, DV001 posisi send, DV002 posisi receive, serta AA016 terbuka, sehingga SCA akan mendorong kapul menuju posisi iradiasi. Dalam perjalanannya kapsul akan melewati 2 sensor, yaitu CG002 dan CG001. Sensor CG002 merupakan Modul sensor laser dengan Seri BF4 dari Autonics. Modul sensor seri BF4 berfungsi untuk mendeteksi kapsul yang melewatinya. Apabila ada kapsul lewat maka sensor akan mengirim pulsa "high" [3]. Pulsa dari sensor CG002 akan diolah komputer untuk menentukan langkah selanjutnya yaitu mengkodisikan katup AA016 dan AA017 tertutup, diverter valve DV001 dan DV002 pada posisi receive, katup AA001 dan AA003 terbuka serta AN001 nyala. Sehingga proses pengiriman kapsul setelah melewati CG002 akan ditangani oleh sistem yang lama, dengan media Gas Nitrogen yang disirkulasikan oleh motor blower AN001, sampai waktu iradiasi selesai. Waktu iradiasi akan aktif apabila kapsul telah melewati sensor CG001. Counter down merupakan penghitung mundur waktu iradiasi, sehingga pada saat nilai counter sudah sama dengan " 0 " maka baru langkah berikutnya dapat berjalan. Pada saat counter $=0$ maka sistem akan mengkondisikan katup AA001 dan AA003 tertutup, membuka katup AA002, AA004, dan AA017. Kondisi motor blower AN001 dan diverter valve DV001 dan DV002 masih seperti semula. Setelah kapsul teriradiasi sampai ke posisi counter station, maka proses iradiasi selesai. Dengan demikian kapsul telah siap dilakukan pengukuran dengan sistem pencacahan spektroskopi gamma.

\section{c) Perancangan Algoritma sub program re-iradiasi}

Hasil perancangan algoritma sub program re-iradiasi ditunjukan seperti pada Gambar 4, di bawah. 


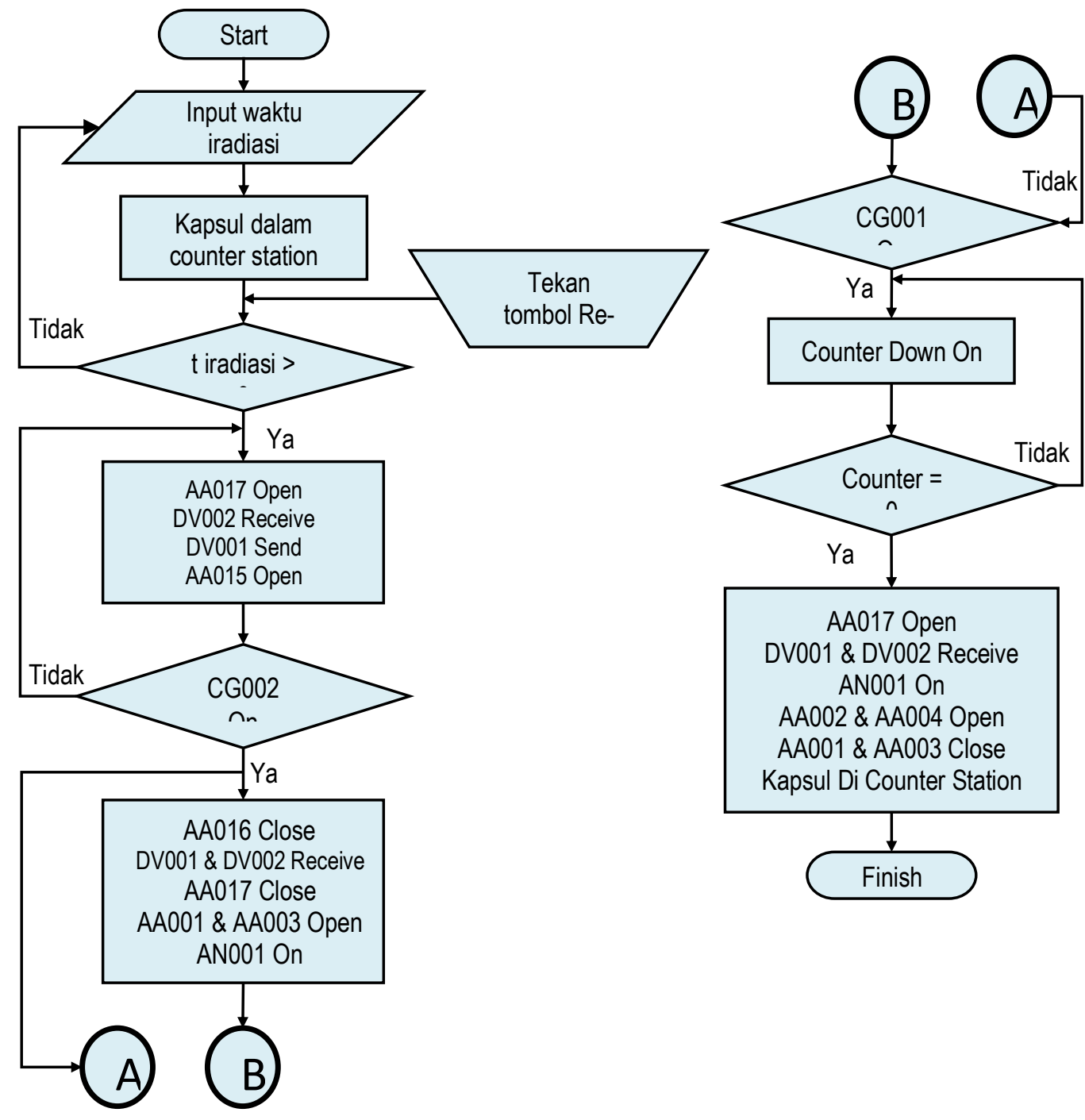

Gambar 4. Algoritma Sub Program Re-Iradiasi

untuk diiradiasi ulang (dikenal dengan

Algoritma sub program re-iradiasi adalah proses pengiriman kapsul teriradiasi dari counter station menuju posisi iradiasi dan kembali lagi ke counter station (iradiasi ulang). Algoritma sub program re-iradiasi pada dasarnya alur perjalanan kapsul sama seperti pada sub program iradiasi, hanya asal kapsul yang berbeda. Kalo re-iradiasi asal kapsul dari counter station, jadi kapsul teriradiasi setelah dilakukan pengukuran dikirim kembali sistem ping pong). Dan perbedaan yang lain yaitu perintah pembukaan katup SCA dilakukan oleh AA015.

\section{d) Perancangan Algoritma sub program waste}

Hasil perancangan Algoritma dari sub program waste ini ditunjukan oleh Gambar 5. sebagai berikut : 


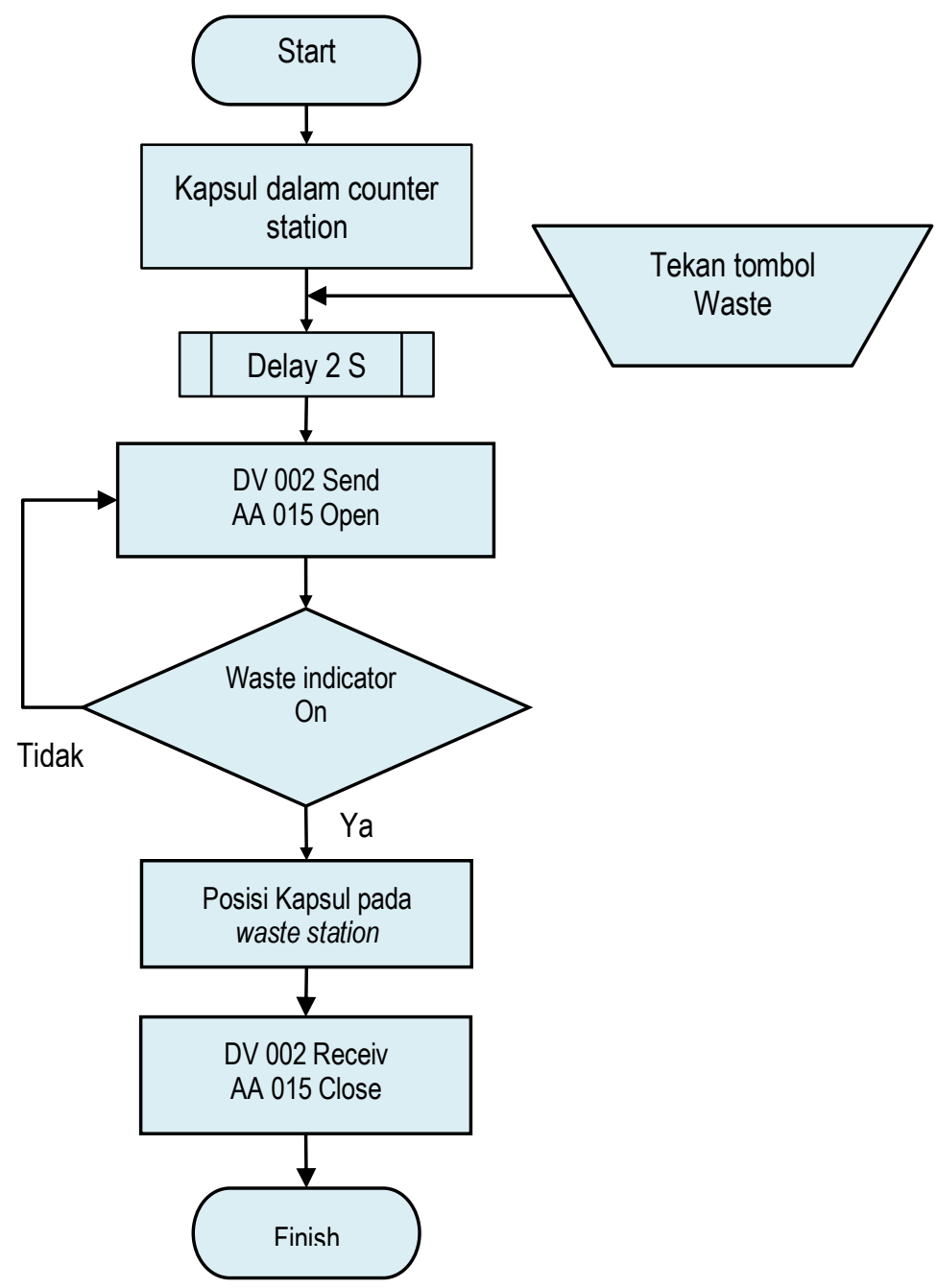

Gambar 5. Algoritma Sub Program Waste

Algoritma sub program waste adalah alur perjalanan kapsul dari counter station setelah dilakukan pengukuran menuju ke tempat penyimpanan limbah kapsul. Proses pengiriman kapsul dari counter station dimulai dengan penekanan tombol waste, dilanjutkan dengan penundaan waktu selama 2 detik. Selanjutnya DV002 akan berpindah posisi dari receive ke posisi send dan AA015 terbuka, sehingga SCA akan mendorong kapsul menuju waste station.
Setelah kapsul sampai di posisi waste station, diverter valve DV002 kembali ke posisi receive dan katup AA015 menutup suplai SCA.

\section{e) Perancangan Algoritma sub program timer}

Hasil peracangan Algoritma untuk sub program timer ditunjukkan seperti pada Gambar 6. 


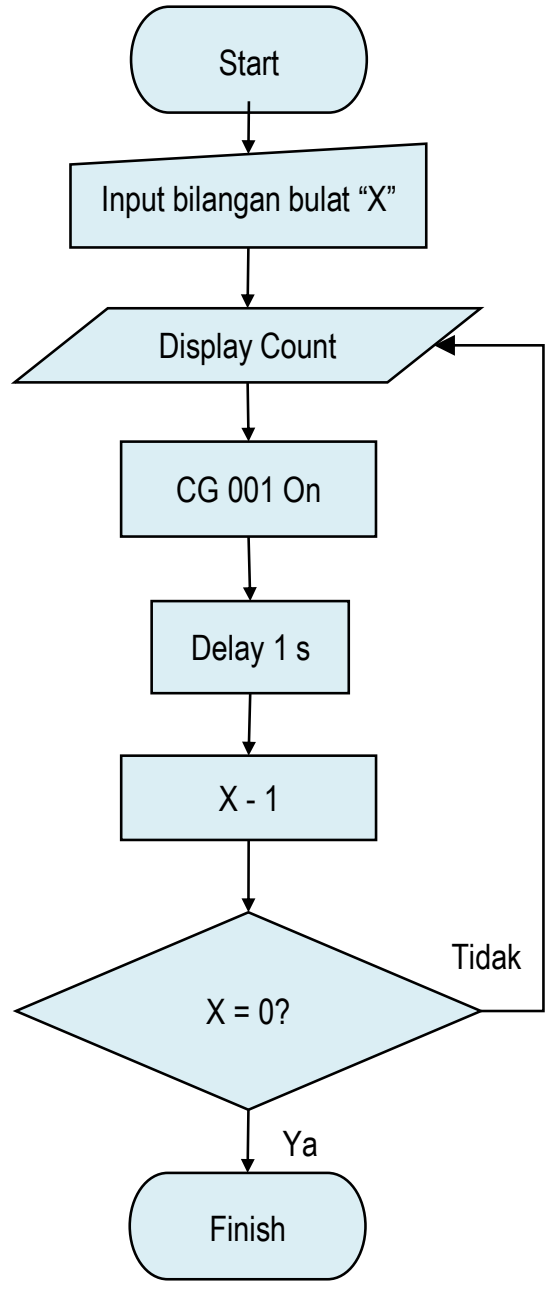

Gambar 6. Algoritma Sub Program Timer

Algoritma sub program timer adalah alur penundaan waktu dari awal proses suatu sistem sampai dengan selesai. Input bilangan bulat $X$ artinya memasukan waktu berapa lama waktu iradiasi dibutuhkan, hal ini disebut dengan waktu iradiasi yang ditampilkan ke layar monitor. Pada saat kapsul melewati sensor CG001, timer aktif setelah 1 detik dan akan dihitung mundur oleh counter. Penghitung mundur dari Counter dengan cara mengurangi waktu iradiasi dengan 1 (satu) atau (X-1). Penghitung counter dinyatakan selesai apabila nilai $X=0$, artinya waktu iradiasi telah habis/selesai. Dengan selesainya waktu iradiasi maka proses selanjutnya akan dijalankan untuk mengirimkan kapsul teriradiasi ke counter station.

Analisis dari perancangan Algoritma yang telah dibuat, yaitu : telah optimal dipaparkan sehingga dalam penyelesaian masalah nantinya dapat diimplementasikan ke dalam bahasa pemrograman pada saat pembuatan perangkat lunak. Kebenaran dari sebuah algoritma adalah menyelesaikan masalah pada saat diberi masukan dan mengeluarkan hasil sesuai dengan rancangan prosesnya. Efisiensi baik, karena tidak mengandung masalah yang dapat memberatkan dalam pembuatan perangkat lunak. Implementasinya mudah, karena tidak terkandung pencabangan yang rumit. Analisis tersebut pada prakteknya tidak akan selalu tepat, oleh karena itu harus berusaha untuk memperbaiki rancangan algoritma yang telah dibuat.

\section{KESIMPULAN}

Dengan terintegrasinya algoritma ke dalam perangkat lunak diharapkan sistem otomatisasi rabbit pneumatik dapat mengirim kapsul target ke posisi iradiasi dan kembali ke counter station. Dan dapat juga dari counter station diping-pong ke posisi iradiasi atau dapat pula dikirim ke waste station untuk dilimbahkan. Sebuah rancangan algoritma dalam prakteknya akan banyak modifikasi dan sangat dinamis sesuai dengan kenyataan dilapangan.

Rancangan ini dapat diaplikasikan dan diintegrasikan ke dalam sistem yang sedang dibangun saat ini "OTOMATISASI SISTEM PENGIRIM KAPSUL PNEUMATIK RABBIT DI REAKTOR RSG-GAS". 


\section{DAFTAR PUSTAKA}

[1] Elisabeth Ratnawati dkk, Evaluasi Waktu Tempuh Kapsul Iradiasi Di Fasilitas Sistem Rabbit RSG-GAS Dengan Menggunakan Variasi Berat Cuplikan, Prosiding Seminar Nasional Teknologi Dan Aplikasi Reaktor Nuklir PRSG Tahun 2014.

[2] Sunarko dkk, Rancangan Sistem Pendeteksian Kapsul Target Pasca Iradiasi Pada Sistem Pneumatic Rabbit Di Reaktor RSG-GAS, Prosiding Seminar Nasional Teknologi dan Aplikasi Reaktor Nuklir PRSG Tahun 2015.

[3] Sunarko dkk, Rancang Bangun Driver Katup Solenoid Sistem Pengirim Kapsul Pneumatic, Prosiding Seminar Nasional Teknologi dan Aplikasi Reaktor PRSG Tahun 2016.

[4] Elisabeth Ratnawati dkk, Pengujian Terhadap Kinerja Fasilitas Iradiasi Sistem Rabbit
Pneumatik Reaktor RSG-GAS Dengan Menggunakan Bahan Acuan Standar, Prosiding Seminar Penelitian Dan Pengelolaan Perangkat Nuklir Pusat Teknologi Akselerator dan Proses Bahan Yogyakarta, 2013.

[5] Ali Ridho Barakbah dkk, Logika dan Algoritma, Politeknik Elektronika Negeri Surabaya, 2013.

[6] Algorithm Data Structures and Problem Solving with $\mathrm{C}++$, Addison-Wesley, 1997.

[7] Dahliar Ananda dkk, Algoritma dan Pemrograman, Politeknik Telkom Bandung, 2009.

[8] Hanapi Ali dkk, Perancangan Sensor Pengukur Kecepatan Kapsul Iradiasi Di Fasilitas Sistem Rabbit Pneumatik, Buletin Pengelolaan Reaktor Nuklir Bulletin, Vol. XV, No. 2, Oktober 2018.

[9] https://bertzzie.com/knowledge/a nalisis-algoritma/Pengenalan DesaindanAnalisisAlgoritma.html 